\title{
EXPERIMENTAL INTRANASAL IMMUNIZATION AGAINST RESPIRATORY VIRUSES
}

\author{
D.I. Zabolotny', O.F.Melnykov ${ }^{1}$, M.Ya. Spivak ${ }^{2,3}$, L.D. Kryvohatska', \\ A.U. Gorlov ${ }^{3}$, V.G. Serdiuk ${ }^{3}$ I.V.Faraon ${ }^{1}$, T.V.Sydorenko', \\ M.D. Tymchenko', L.P. Babenko', A.O. Shevchuk ${ }^{3}$ \\ ${ }^{I}$ SI "Institute of Otolaryngology named after prof. O.S. Kolomyichenko of the NAMS of Ukraine", \\ 3 Zoologichna Str., Kyiv, 02000, Ukraine \\ ${ }^{2}$ Zabolotny Institute of Microbiology and Virology, NAS of Ukraine, \\ 154 Acad. Zabolotny Str., Kyiv, 03143, Ukraine \\ ${ }^{3}$ PJSC "SPC Diaproph-Med", \\ 35 Svetlitskogo Str., Kyiv, 04123, Ukraine \\ e-mail:n.spivak@ukr.net
}

\begin{abstract}
The most common method of influenza prevention is intramuscular administration of vaccines, which causes a higher antibody response than subcutaneous. However, such routes of antigens administration result in the predominant formation of serum IgG against influenza viruses, while intranasal administration promotes higher titers of both $\operatorname{IgG}$ and IgA than intramuscular vaccination. Based on the fact that this infectious agent enters the body through the mucous membranes of the respiratory tract, we developed the concept of local etiologically adequate vaccination, based on the statement that the vaccine should be administered in the same way as the infection, i.e. in cases of respiratory infections it should be intranasal or oral administration of vaccine material. So, the aim of this work was to demonstrate the benefits of local vaccination against respiratory viruses, as well as the use of nanocarriers in such vaccination and possible cross-antigen reactions by hemagglutinin between antigens of influenza virus and severe acute respiratory syndrome-related coronavirus 2 (SARS-CoV-2). Methods. The study was performed using Wistar rats in 3 series of experiments. At first series we investigated the comparative immune response to influenza Influvac ${ }^{\circledR}$ vaccine (Abbott, The Netherlands) against $A$ and B type influenza viruses, which was administered intranasally, per os and subcutaneously once at a dose of $1.5 \mu \mathrm{g}$ of hemagglutinin. Animals from group 2 were similarly administered with the same amount of vaccine with and without cerium dioxide nanoparticles $\left(\mathrm{CeO}_{2}\right.$ ). Animals of group 3 intranasally received an identical volume of sodium chloride solution (placebo control). Rats were removed from the experiment by decapitation one week after the immunization. Tissue homogenates were prepared from the trachea of animals of all groups by homogenization at the rate of $100 \mathrm{mg} / \mathrm{mL}$ of $0.9 \%$ sodium chloride solution. The homogenates were kept at $2{ }^{\circ} \mathrm{C}$ for 18 hours and then centrifuged at $120 \mathrm{~g}$ for 20 minutes (cold centrifuge NF800R, Turkey). The obtained extracts and sera were stored at a temperature of $-20{ }^{\circ} \mathrm{C}$ until the determination of antibodies titers to hemagglutinins of $A$ and $B$ influenza viruses in the reaction of hemagglutination inhibition and titers of interferons (IFN) $-\alpha$ and $-\gamma$ and using enzyme-linked immunosorbent assay using Elabscience (USA) reagents and Stat Fax 2100 Microplate Reader (USA). In the $3^{\text {rd }}$ series of experiments, the content of antihemagglutinins in the trachea and serum after immunization of animals with nucleocapsid antigen of SARS-Cov-2 coronavirus (recombinant antigen produced by PJSC SPC "Diaproph-Med", Ukraine) at a dose of $2.5 \mu \mathrm{g}$ in $0.2 \mathrm{~mL}$ of Hanks' solution was determined. The antigen was administered intranasally or subcutaneously and then all other steps of the experiments were similar to those described below for the $1^{{ }^{s t}}$ series of experiments. Results. Conducted experimental studies aimed to develop new approaches and technologies for vaccination against respiratory viruses, which enter mainly through the upper respiratory tract, confirm the concept of the feasibility of local intranasal vaccination against influenza and other respiratory viruses. The data obtained during the research confirm more effective appearance of protective local immunity both in terms of humoral immune response and interferon protection of the respiratory tract during intranasal vaccination. The use of cerium dioxide nanoparticles in local vaccination may increase the effectiveness of this approach to stimulate the production of antibodies to influenza virus antigens in the upper respiratory tract. Finally, the advantages of local intranasal immunization with SARS-CoV-2 N-antigens over their systemic administration suggest that local intranasal vaccination
\end{abstract}


against coronavirus antigens may also be more effective than systemic administration of antigens of this virus, which requires further research for clinical trials. Conclusions. Intranasal immunization of animals with influenza $A$ and $B$ virus antigens and $N$-antigen of SARS CoV-2 is more effective for creating local protective immunity in the respiratory system compared to parenteral administration of the antigen. The use of cerium dioxide nanoparticles together with the vaccine resulted in more effective local immune response to respiratory virus antigens.

Keywords: respiratory viruses, local immunity, nanoparticles, vaccination concept.

Recurrent upper respiratory infections are a global health problem $[1,2]$. In developed countries, up to $25 \%$ of patients of all ages suffer from recurrent respiratory infections $[2,3]$, among which influenza is one of the most common.

One of the effective methods of influenza prevention is vaccination [4-6]. The drugs used for vaccination are based on a holistic inactivated influenza virus and split vaccines for intramuscular administration and live attenuated influenza vaccines for intranasal administration $[4,7,8]$. The effectiveness of such immunoprophylactic measures does not exceed $60 \%[4,8]$, in addition, post-vaccination immunity is short-lived $[4,9]$ in contrast to immunity that remains after a flu infection $[7,10]$.

The most common is intramuscular administration of vaccines [7,11], which causes a higher antibody response than subcutaneous [5, 12]. However, such routes of antigenic administration result in the predominant formation of serum IgG against influenza viruses [11], while intranasal administration promotes higher titers of both $\operatorname{IgG}$ and IgA than intramuscular vaccination [13]. In addition, the weakened live vaccine when applied to the mucous membrane of the respiratory tract leads to the predominant formation of secretory IgA in them which prevents the entry of influenza viruses into the human body [11].

Based on the fact that this infectious agent enters the body through the mucous membranes of the respiratory tract, we at the SI "Institute of Otolaryngology named after prof. O.S. Kolomyichenko of the NAMS of Ukraine" developed the concept of local etiologically adequate vaccination, based on the statement that the vaccine should be administered in the same way as the infection, i.e. in cases of respiratory infections it should be intranasal or oral administration of vaccine material $[9,14]$. So, the aim of this work was to demonstrate the benefits of local vaccination against respiratory viruses, as well as the use of nanocarriers in such vaccination and possible cross-antigen reactions by hemagglutinin between antigens of influenza virus and severe acute respiratory syndrome-related coronavirus 2 (SARS-CoV-2).

Materials and methods. The study was performed using 75 Wistar rats weighing 190 $220 \mathrm{~g}$ from the vivarium of the Institute. 3 series of experiments were conducted. At first we investigated the comparative immune response to influenza Influvac ${ }^{\circledR}$ vaccine (Abbott, The Netherlands) against A and B type influenza viruses, which was administered intranasally, per os and subcutaneously once at a dose of $1.5 \mu \mathrm{g}$ of hemagglutinin in $0.1 \mathrm{~mL}$ of Hanks solution per one administration. Animals were removed from the experiment on the $11^{\text {th }}$ day after immunization with humane treatment, according to the "European Convention for the Protection of Vertebrate Animals Used for Experimental and Other Scientific Purposes" (Strasbourg, 1986).

17 animals from group 2 were similarly administered with the same amount of vaccine with and without cerium dioxide nanoparticles $\left(\mathrm{CeO}_{2}\right)$. 5 animals of group 3 intranasally received an identical volume of sodium chloride solution (placebo control). Rats were removed from the experiment by decapitation one week after immunization. Tissue homogenates were prepared from the trachea of animals of both groups by homogenization at the rate of $100 \mathrm{mg} / \mathrm{mL}$ of $0.9 \%$ sodium chloride solution. The homogenates were kept at $2{ }^{\circ} \mathrm{C}$ for 18 hours and then centrifuged at $120 \mathrm{~g}$ for 20 minutes (cold centrifuge NF800R, Turkey). The obtained extracts and sera were stored at a temperature of $-20{ }^{\circ} \mathrm{C}$ until the determination of antibodies titers to hemagglutinins of A and B influenza viruses in the reaction of hemagglutination inhibition [15] and titers of interferons (IFN) $-\alpha$ and $-\gamma$ using enzymelinked immunosorbent assay using Elabscience (USA) reagents and Stat Fax 2100 Microplate Reader (USA).

The content of antibodies and interferons in the trachea and serum during immunization of animals with influenza vaccine with the addition of cerium dioxide nanoparticles $\left(\mathrm{CeO}_{2}\right)$ and without it was determined in the second series 
of experiments. In the $3^{\text {rd }}$ series, the content of antihemagglutinins in the trachea and serum after immunization of animals with nucleocapsid antigen of SARS-Cov-2 coronavirus (recombinant antigen produced by PJSC SPC “Diaproph-Med”, Ukraine) at a dose of $2.5 \mu \mathrm{g}$ in $0.2 \mathrm{~mL}$ of Hanks' solution was determined. The antigen was administered intranasally or subcutaneously and then all other steps of the experiments were similar to those described below for the $1^{\text {st }}$ series of experiments. Antibody titers to hemagglutinin were statistically processed using the $\mathrm{U}$ criterion (Wilcoxon Rank Sum Test), and antibody titers according to the recommendations of V.I. Levenson [16, 17].

Results. When Influvac $\AA$ vaccine was used for immunization of animals (Table 1), which was administered intranasally, per os and subcutaneously, different levels of antibodies to hemagglutinin were obtained in serum and in extracts from tracheal tissues.

The titers of antibodies to hemagglutinin of influenza virus in tracheal extract significantly exceed $(\mathrm{p}<0.01)$ control values and the level of antibodies in the serum after a single administration of influenza vaccine per os. After intranasal administration the content of antibodies to hemagglutinin in extracts from tracheal tissues was significantly higher compared to the content of antibodies in serum $(\mathrm{p}<0.01)$.

It is seen from the data presented in Table 1 that after intranasal administration of influenza vaccine the level of antibodies to hemagglutinin in the extracts of the trachea was significantly higher than in serum. No significant difference was found when comparing two groups of studies by the level of antibodies in the blood, whereas in the extracts of the trachea, the level of titers of antibodies to hemagglutinin was 1.5 times higher. According to O.A. Shydlovska [18] the use of cerium dioxide nanoparticles increases the titers of antibodies to hemagglutinin of influenza virus in the blood in the case of parenteral vaccination under experimental conditions. After intranasal vaccination, nanoparticles improve the forma tion of humoral local immunity against influenza virus.

The interferon system is a major component of antiviral immune defense. Interferons implement a congenital nonspecific local and systemic body

\section{Table 1}

\section{The content of antibodies to hemagglutinin of influenza $A$ and $B$ viruses in different}

immunization types

\begin{tabular}{|c|c|c|}
\hline \multirow{4}{*}{$\begin{array}{l}\text { The method of antigen } \\
\text { administration }\end{array}$} & \multicolumn{2}{|c|}{ Antibody titers, $\log _{2}$} \\
\hline & Blood serum & Extracts from tracheal tissues \\
\hline & $\mathrm{I}$ & II \\
\hline & $\mathrm{M} \pm \mathrm{m}$ & $\mathrm{M} \pm \mathrm{m}$ \\
\hline & & $2.75 \pm 0.16$ \\
\hline Intact anımals & $4.29 \pm 0.61$ & $(\mathrm{n}=8)$ \\
\hline (control) & & $\mathrm{p}_{\mathrm{I} / \mathrm{II}}<0.07$ \\
\hline & & $8.67 \pm 0.21 * *$ \\
\hline Intranasal administration & $6.80 \pm 0.20$ & $(\mathrm{n}=7)$ \\
\hline (A) & $(\mathrm{n}=7)$ & $\mathrm{p}_{\mathrm{I} / \mathrm{II}}<0.01$ \\
\hline & & $8.36 \pm 0.31 * *$ \\
\hline Per os administration & $6.50 \pm 0.29$ & $(\mathrm{n}=11)$ \\
\hline (B) & $(n=12)$ & $\mathrm{p}_{\mathrm{I} / \mathrm{II}}<0.01$ \\
\hline & $\mathrm{p}_{\mathrm{A} / \mathrm{B}}>0.03$ & $\mathrm{p}_{\mathrm{A} / \mathrm{B}}>0.05$ \\
\hline & & $4.25 \pm 0.45^{* *}$ \\
\hline Subcutaneous administration & $\begin{array}{c}5.00 \pm 0.20 \\
(n=7)\end{array}$ & $(\mathrm{n}=8)$ \\
\hline & $n<005$ & $\mathrm{p}_{\mathrm{I} / \mathrm{II}}>0.05$ \\
\hline (C) & $\mathrm{p}_{\mathrm{A} / \mathrm{C}}<0.05$ & $\mathrm{p}_{\mathrm{A} / \mathrm{C}}<0.01$ \\
\hline & $\mathrm{p}_{\mathrm{B} / \mathrm{C}}>0.05$ & $\mathrm{p}_{\mathrm{B} / \mathrm{C}}<0.01$ \\
\hline
\end{tabular}

* - Significance of differences in comparison with control: ${ }^{*}-\mathrm{p}<0.05$;

$* *-\mathrm{p}<0.01 ; \mathrm{n}-$ Number of samples 
response to viral infection. They form a protective barrier in the way of viruses earlier than specific protective reactions of the body [19]. There is evidence that antiviral vaccines not only stimulate humoral and cellular immunity, but also affect the interferon system $[10,20]$. Therefore, the next step was to determine the levels of IFN- $\alpha$ and IFN- $\gamma$ in tracheal extracts and blood serum of animals before and after various types of local vaccination against influenza. The results obtained are presented in Table 3 .

As can be seen from the Table $3, \mathrm{CeO}_{2}$ in combination with the influenza vaccine in cases of intranasal administration reduced the level of IFN- $\alpha$ in the blood and had tendency to increase the content of IFN- $\gamma$ in trachea extracts of rats. Thus, the use of cerium dioxide nanoparticles with influenza vaccine when administered intranasally increased the level of humoral antiviral immunity factors in the respiratory system.

In recent years, special interest has arisen in connection with the spread of the respiratory virus SARS-CoV-2. The presence of hemagglutinin in the structure of this virus somewhat converges influenza $A$ and $B$ and SARS-CoV-2 viruses and suggests the possibility of diagnosing the immune response to these respiratory viruses by the level of antibodies to hemagglutinin [12]. To confirm the existence of possible cross-reactions between coronavirus and influenza A and B viruses, experimental animals were immunized intranasally and subcutaneously with a nucleocapsid-type antigen of SARS-CoV-2 with a molecular weight of $49 \mathrm{kDa}$.

As in experiments with influenza vaccine, the coronavirus antigen was administered in the same dose $(2.5 \mu \mathrm{g})$ once intranasally and subcutaneously and after 10 days animals were tested for the presence of antibodies to hemagglutinin of influenza A and B viruses,

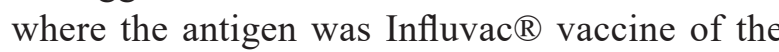
2020/2021 season with initial hemagglutinating titer of 1:400. The obtained results are presented in Fig. 1, from which it is clear that after intranasal administration of coronavirus antigen, the content of antibodies in tracheal extract was higher than

Table 2

Titers of antibodies to hemagglutinins of influenza viruses in blood serum and tracheal extracts with the use of cerium dioxide nanoparticles and intranasal vaccine

\begin{tabular}{|l|c|c|c|c|}
\hline \multirow{2}{*}{ Indicators } & \multicolumn{2}{|c|}{ Titers of antibodies to hemagglutinins of influenza A and B viruses } \\
\cline { 2 - 5 } & \multicolumn{2}{|c|}{ Extracts from tracheal tissues } & \multicolumn{2}{c|}{ Blood serum } \\
\cline { 2 - 5 } & \multicolumn{2}{|c|}{ Variant of local vaccination } & $\mathrm{CeO}_{2}+$ & $\mathrm{CeO}_{2}-$ \\
\cline { 2 - 5 } & $\mathrm{CeO}_{2}+$ & $\mathrm{CeO}_{2}-$ & $1: 45.5$ & $1: 35.5$ \\
\hline Average titer & $1: 170.5^{*}$ & $1: 68.5$ & $0-1: 80$ & $0-1: 160$ \\
\hline min-max & $1: 20-1: 640$ & $1: 20-1: 160$ & 17 & 18 \\
\hline $\mathrm{n}^{* *}$ & 18 & 16 & $1: 15.8(0-1: 40)$ \\
\hline Intact animals & $\mathrm{n}=10$ & \multicolumn{3}{|c}{} \\
\hline
\end{tabular}

* - Significance of differences between groups

** - Number of samples

\section{Table 3}

Influence of influenza vaccine on the content of IFN- $\alpha$ and $-\gamma$ after its intranasal administration both separately and with cerium dioxide nanoparticles $\left(\mathrm{CeO}_{2}\right)$

\begin{tabular}{|c|c|c|c|c|}
\hline \multirow{3}{*}{ Indicators } & \multicolumn{4}{|c|}{ Blood serum } \\
\hline & \multicolumn{2}{|c|}{ IFN- $\alpha, p g / m L$} & \multicolumn{2}{|c|}{ IFN- $\gamma, \mathrm{pg} / \mathrm{mL}$} \\
\hline & Vaccine $+\mathrm{CeO}_{2}$ & Vaccine & Vaccine $+\mathrm{CeO}_{2}$ & Vaccine \\
\hline $\mathrm{n}^{*}$ & 10 & 10 & 10 & 10 \\
\hline $\mathrm{M} \pm \mathrm{m}$ & $1.1 \pm 0.6$ & $6.9 \pm 2.5$ & $8.6 \pm 5.0$ & $1.3 \pm 1.0$ \\
\hline $\mathrm{p}$ & \multicolumn{2}{|c|}{$\mathrm{p}<0.05$} & \multicolumn{2}{|c|}{$\mathrm{p}=0.20$} \\
\hline \multirow{3}{*}{ Indicators } & \multicolumn{4}{|c|}{ Extracts from tracheal tissues } \\
\hline & \multicolumn{2}{|c|}{ IFN- $\alpha, p g / m L$} & \multicolumn{2}{|c|}{ IFN- $\gamma, \mathrm{pg} / \mathrm{mL}$} \\
\hline & Vaccine $+\mathrm{CeO}_{2}$ & Vaccine & Vaccine $+\mathrm{CeO}_{2}$ & Vaccine \\
\hline $\mathrm{n}^{*}$ & 12 & 12 & 12 & 12 \\
\hline $\mathrm{M} \pm \mathrm{m}$ & $128.0 \pm 32.9$ & $180.9 \pm 10.6$ & $284.6 \pm 42.3$ & $180.1 \pm 20.3$ \\
\hline $\mathrm{p}$ & \multicolumn{2}{|c|}{$\mathrm{p}=0.50$} & \multicolumn{2}{|c|}{$\mathrm{p}=0.07$} \\
\hline
\end{tabular}

* - Number of samples 


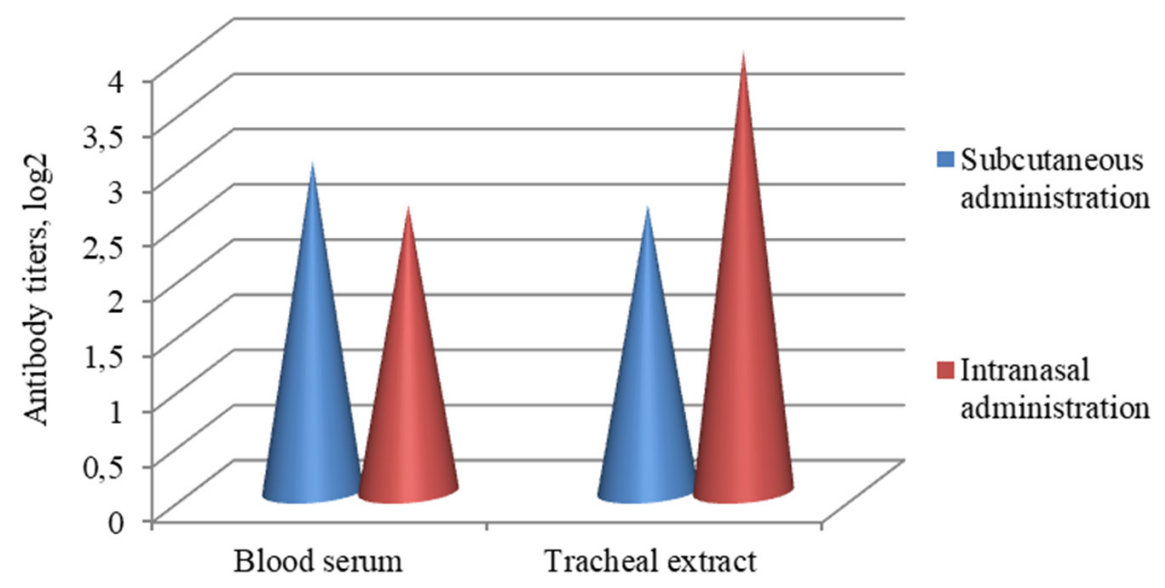

F i g. 1. Titers of antibodies to coronavirus hemagglutinin in different variants of immunization

after subcutaneous administration and exceeds the titers of antibodies to hemagglutinin in blood serum.

Discussion. Thus, our experimental studies aimed to develop new approaches and technologies for vaccination against respiratory viruses, which enter mainly through the upper respiratory tract, confirm the concept of the feasibility of local intranasal vaccination against influenza and other respiratory viruses. The data obtained during the research on more effective appearance of protective local immunity both in terms of humoral immune response and interferon protection of the respiratory tract during intranasal vaccination coincide with the data of other authors [13, 14]. In particular, based on their observations, Zheng $Z$ et al. predict that noninvasive vaccine administration will be more widely applied in the clinic in the near future [21]. Pedersen $G$ et al. studied antigen transport into the central nervous system following intranasal immunization against influenza and discuss possible reasons for the superiority of the intranasal as compared with the sublingual route in terms of vaccine immunogenicity [22].

The use of cerium dioxide nanoparticles in local vaccination may increase the effectiveness of this approach to stimulate the production of antibodies to influenza virus antigens in the upper respiratory tract and these data coincide with the results of studies of nanoparticles ability to increase the level of protective antibodies to influenza in blood serum in cases of systemic immunization of animals [18, 23]. In particular, Al-Halifa $\mathrm{S}$ et al. provides an overview of the advantages associated with the use of nanoparticles as vaccine delivery platforms to immunize against respiratory viruses and highlights relevant examples demonstrating their potential as safe, effective and affordable vaccines [24]. Cossette $\mathrm{B}$ et al. discuss promising strategies across a wide array of biomaterial classes and highlight the considerable potential of intranasal vaccines and the biomaterial-based technologies that enable them [25]. Marasini $\mathrm{N}$ et al. summarizes challenges and the rationale for nasal vaccine development with a special focus on the use of nanoparticles based on polymers and lipids for mucosal vaccine delivery [26].

Finally, the advantages of local intranasal immunization with SARS-CoV-2 N-antigens over their systemic administration suggest that local intranasal vaccination against coronavirus antigens may also be more effective than systemic administration of antigens of this virus, which requires further research for clinical trials.

Conclusions. Intranasal immunization of animals with influenza $A$ and $B$ virus antigens and $\mathrm{N}$-antigen of SARS CoV-2 is more effective for creating local protective immunity in the respiratory system compared to parenteral administration of the antigen. The use of cerium dioxide nanoparticles together with the vaccine resulted in more effective local immune response to respiratory virus antigens.

Acknowledgments. The authors express their gratitude to the senior researcher of the department of problems of interferon and immunomodulators of the D.K. Zabolotny Institute of Microbiology and Virology of NASU, Ph.D. Zholobak N.M. 


\section{ЕКСПЕРИМЕНТАЛЬНА ІНТРАНАЗАЛЬНА ІМУНІЗАЦІЯ ПРОТИ РЕСПІРАТОРНИХ ВІРУСІВ}

Д.І. Заболотний, О.Ф. Мельников ${ }^{1}$, М.Я. Співак ${ }^{2,3}$, Л.Д. Кривохатська А.Ю. Горлов ${ }^{3}$, В.Г. Сердюк ${ }^{3}$ І.В. Фараон ${ }^{1}$, Т.В. Сидоренко ${ }^{\prime}$, М.Д. Тимченко ${ }^{1}$, Л.П. Бабенко ${ }^{2}$ А.О. Шевчук

'ДУ «Інститут отоларингології ім. проф. О.С. Коломійченка НАМН України», вул. Зоологічна, 3, Київ, 02000, Украӥна ${ }^{2}$ Інститут мікробіології і вірусології ім. Д.К. Заболотного НАН України, вул. Академіка Заболотного, 154, Київ, 03143, Україна

${ }^{3} \Pi p A T$ «НВК Діапроф-Мед», вул. Світлицького, 35, Київ, 04123, Украӥна

Резюме

Найбільш поширеним методом імунопрофілактики грипу є внутрішньом'язове введення вакцинальних препаратів, що забезпечує продукцію більш високих титрів антитіл, ніж підшкірне. Однак, такі шляхи введення антигенного матеріалу обумовлюють утворення переважно сироваткового $\operatorname{IgG~проти~вірусів~грипу,~тоді~як~інтраназальне~вве-~}$ дення сприяє досягненню більш високих титрів як $\operatorname{IgG}$, так i IgA, ніж внутрішньом'язова вакцинація. Виходячи $з$ того, що цей інфекційний агент потрапляє в організм крізь слизові оболонки дихальних шляхів, нами була розроблена концепція локальної етіологічно адекватної вакцинації, основою якої є положення про те, що введення вакцини потрібно робити тим самим шляхом, по якому розвивається інфікування, тобто при респіраторних інфекціях це повинно бути інтраназальне або оральне введення вакцинального матеріалу. Дану роботу було проведено з метою встановлення переваг локальної вакцинації проти респіраторних вірусів, а також застосування наноносіїв за такої вакцинації і можливих перехресних реакцій по антигену-гемаглютиніну між антигенами вірусу грипу i SARSCov-2. Методи. Дослідження проведені на щурах лінії Wistar в 3-х серіях, де в 1-ій досліджували імунну відповідь на вакцину проти грипу А і В типу «Інфлувак» (Франція), яку вводили інтраназально, per os та підшкірно однократно в дозі 1,5 мкг гемаглютиніну. Тваринам групи 2 аналогічним чином вводили таку саму кількість вакцини без наночасток діоксиду церію $\left(\mathrm{CeO}_{2}\right)$ та 3 ними. Тварини з групи 3 інтраназально отримували ідентичний об'єм розчину хлориду натрію (плацебо контроль). Щурів виводили з досліду шляхом декапітації через тиждень після імунізації. 3 трахей тварин обох груп шляхом гомогенізації готували тканинні гомогенати з розрахунку 100 мг/мл 0,9\% розчину хлориду натрію. Гомогенати витримували протягом 18 годин за температури $2{ }^{\circ} \mathrm{C}$ та центрифугували при $120 \mathrm{~g}$ протягом 20 хвилин (холодова центрифуга NF800R, Туреччина). Отримані екстракти та сироватки зберігали за температури $-20{ }^{\circ} \mathrm{C}$ до визначення в них титрів антитіл до гемаглютинінів вірусів грипу А та В у реакції гальмування гемаглютинації та інтерферонів- $\gamma$ та - $\alpha$ за допомогою імуноферментного методу з застосуванням реактивів фірми Elabscience (США) та імуноферментного аналізатора Stat Fax 2100 (США). Було визначено вміст антигемаглютинінів в трахеї та сироватці при імунізації тварин нуклеокапсидним антигеном коронавірусу SARS-CoV-2 (рекомбінантний антиген виробництва ПрАТ НВК «Діапроф-Мед», Україна) в дозі 2,5 мкг/0,2 мл розчину Хенкса. Антиген вводили інтраназально або підшкірно з подальшим отриманням матеріалу від тварин за аналогічною схемою. Результати. Проведені експериментальні дослідження з визначення ефективності вакцинації проти респіраторних вірусів, які потрапляють переважно через верхні дихальні шляхи, підтверджують положення концепції про доцільність локальної інтраназальної вакцинації проти грипу та інших вірусів респіраторної групи. Отримані в ході досліджень дані підтверджують більшу ефективність інтраназальної вакцинації як за параметрами розвитку гуморальної імунної відповіді, так і інтерферонового захисту дихальних шляхів. Застосування наночасток діоксиду церію за локальної вакцинації підсилювало продукцію антитіл до антигенів вірусу грипу саме у верхніх дихальних шляхах. Доведені переваги локальної інтраназальної імунізації зі застосуванням N-антигенів SARS-Cov-2 у порівнянні з їх системним введенням дозволяють зробити припущення, що локальна інтраназальна вакцинація і проти антигенів коронавірусу також може бути більш ефективною у порівнянні зі системним введенням антигенів цього вірусу, що потребує подальших досліджень та клінічних випробувань. Висновки. Було показано, що інтраназальна імунізація тварин антигенами вірусу грипу А і В та $\mathrm{N}$-антигеном SARS-CoV-2 більш ефективна для створення локального протективного імунітету в органах дихання у порівнянні з парентеральним введенням антигену. Застосування наночасток ді- 
оксиду церію разом із вакциною супроводжується більш ефективною локальною імунною відповіддю на антигени респіраторних вірусів.

1. De Benedictis FM, Bush A. Recurrent lower respiratory tract infections in children. BMJ. 2018; 362:k2698.

2. Goetzel RZ, Hawkins K, Ozminkowski RJ, Wang $\mathrm{S}$. The health and productivity cost bur den of the "top 10" physical and mental health conditions affecting six large U.S. employers in 1999. J Occup Environ Med. 2003; 45(1):5-14.

3. GBD 2015 LRI Collaborators. Estimates of the global, regional, and national morbidity, mortality, and aetiologies of lower respiratory tract infections in 195 countries: a systematic analysis for the Global Burden of Disease Study 2015. Lancet Infect Dis. 2017; 17:1133-1161.

4. Dhakal S, Klein SL. Host Factors Impact Vaccine Efficacy: Implications for Seasonal and Universal Influenza Vaccinograms. J Virol. 2019; 93(21):e00797-19. doi:10.1128/JVI.00797-19.

5. Madsen A, Cox RJ. Prospects and Challenges in the Development of Universal Influenza Vaccines. Vaccines (Basel). 2020; 8(3):361. doi:10.3390/vaccines 8030361

6. Wagner A, Weinberger B. Vaccines to Prevent Infectious Diseases in the Older Population: Immunological Challenges and Future Perspectives. Front Immunol. 2020; 11:717. doi:10.3389/fimmu.2020.00717

7. Bouvier NM. The Future of Influenza Vaccines: A Historical and Clinical Perspective. Vaccines (Basel). 2018; 6(3):58. doi:10.3390/vaccines6030058

8. Fulop T, Franceschi C, Hirokawa K, Pawelec G. Immunosenescence Modulation by Vaccination. Handbook of Immunosenescence. 2019; 26812705. doi:10.1007/978-3-319-99375-1_71

9. Melnikov OF, Zabolotna DD, Rilska OG. [The concept of local etiologically adequate vaccination with respiratory virus and influenza antigens]. Immunology and allergology: science and practice. 2015; 3-4:64--68. Ukrainian.

10. Wang TT, Bournazos S, Ravetch JV. Immunological responses to influenza vaccination: lessons for improving vaccine efficacy. Curr Opin
Ключові слова: респіраторні віруси, локальний імунітет, наночастки, концепція вакцинації.

Immunol. 2018; 53:124-129. doi:10.1016/ j. coi.2018.04.026

11. Tamura SI, Ainai A, Suzuki T, Kurata H. Hasegawa Intranasal Inactivated Influenza Vaccines: a Reasonable Approach to Improve the Efficacy of Influenza Vaccine? Jpn J Infect Dis. 2016; 69(3):165-79. doi:10.7883/yoken.JJID.2015. 560

12. Kharchenko EP. [Coronavirus SARS Cov-2: features of structural proteins contagiousness and possible immune collisions]. Epidemiology and Vaccine Prevention. 2020; 19(2):13-30. Russian.

13. Lee KL, Twyman RM, Fiering S, Steinmetz N. Virus-based nanoparticles as platform technologies for modern vaccines. Interdiscip Rev Nanomed Nanobiotechnol. 2016; 8(4):554-578. doi:10.1002/wnan.1383

14. Melnikov OF, Peleshenko NO, Sidorenko TV, Timchenko MD, Timchenko SV. [A method of increasing vaccine antiviral immunity]. Patent of Ukraine No. 8751110 Feb. 2014. Ukrainian.

15. Kabat EE, Mayer M. [Experimental immunochemistry]. Moscow: Mir (translated from English); 1968. 680 p. Russian.

16. Gubler EV. Computational methods of analysis and recognition of pathological processes. Moscow: Medicine; 1978. 296 p. Russian.

17. Levenson VI. [Method for statistical processing of titration]. Proceedings of the Moscow Research Institute of Epidemiology and Microbiology. 1968-1969. 12:72. Russian.

18. Shidlovskaya OA. [Antiviral action of cerium dioxin nanoparticles and nanobiocomposites based on it]; dissertation. Kyiv: Zabolotny Institute of Microbiology and Virology, NAS of Ukraine; 2018. 165 p. Ukrainian.

19. Sun W, Luo T, Liu W, Li J. Progress in the Development of Universal Influenza Vaccines. Viruses. 2020; 12(9):1033. doi:10.3390/v12091033

20. Lutskiy AA, Zhirkov AA, Lobzin DY. [Interferon- $\gamma$ : biological functions and significance for the diagnosis of cellular immune response]. Journal of Infectology. 2015; 7(4):5-10. Russian. 
21. Zheng Z, Diaz-Arévalo D, Guan H, Zeng M. Noninvasive vaccination against infectious diseases. Hum Vaccin Immunother. 2018; 14(7): 1717-1733. doi:10.1080/21645515.2018.14612 96

22. Pedersen G, Cox R. The mucosal vaccine quandary: intranasal vs. sublingual immunization against influenza. Hum Vaccin Immunother. 2012; 8(5):689-693. doi:10.4161/hv.19568

23. Melnikov OF, Zabolotna DD, Prylutska OD. [Method of influenza immunoprophylaxis]. Patent of Ukraine No. 13378124 Apr. 2019. Ukrainian.
24. Al-Halifa S, Gauthier L, Arpin D, Bourgault S, Archambault D. Nanoparticle-Based Vaccines Against Respiratory Viruses. Front Immunol. 2019; 10:22. doi:10.3389/fimmu.2019.00022

25. Cossette B, Kelly SH, Collier JH. Intranasal Subunit Vaccination Strategies Employing Nanomaterials and Biomaterials. ACS Biomater Sci Eng. 2021; 7(5): 1765-1779. doi:10.1021/acsbiomaterials.0c01291

26. Marasini N, Skwarczynski M, Toth I. Intranasal delivery of nanoparticle-based vaccines. Ther Deliv. 2017; 8(3):151-167. doi:10.4155/tde2016-0068

Received 22.04.2021 